\title{
English Language Teacher Professional Development: When Institutional Frameworks Fall Short
}

\author{
Alev ÖZBiLGiN* \\ Besime ERKMEN* \\ Middle East Technical University, Northern Cyprus Campus
}

A. Cendel kARAman

Middle East Technical University

\begin{abstract}
:
In the last couple of decades, teachers' professional development has received much attention in the field of teacher education. In addition to maximizing quality in preparing English language teachers in pre-service programs, efforts have also been directed towards enhancing ongoing in-service professional development worldwide. The way these needs are addressed vary across nations based on policies and institutional frameworks. The purpose of this paper is to discuss EFL teachers' beliefs, experiences, and their needs regarding professional development in a particular context: Northern Cyprus. In particular, teachers' visions, self, and their role in relation to development were examined. Interviews with 12 teachers in three different cities were carried out. Our findings indicate that if institutional support for professional development is unavailable or insufficient, teachers rely on their own resources. Their preference, however, is to be part of the system that supports and appreciates their efforts. The findings also imply that these teachers are aware of the constraints in the system and they highlight that a needs analysis should be carried out to design professional development activities that meet teachers' needs and interests. Based on the findings, recommendations are made to the governing bodies.
\end{abstract}

Keywords: Teacher Professional Development, Teacher Education, Teacher Beliefs

İnönü University

Journal of the Faculty of Education

Vol 17, No 1, 2016

pp. $55-65$

DOI: $10.17679 /$ iuefd. 17152899

\section{Suggested Citation}

Özbilgin, A., Erkmen, B. \& Karaman, A. C. (2016). English language teacher professional development: When institutional frameworks fall short, The Inonu University Journal of the Faculty of Education, 17(1), 55-65. DOI: 10.17679/iuefd.17152899 


\section{INTRODUCTION}

Most professional development activities in the 1980s and 1990s were based on one-shot workshops or short-term courses, which lead to stagnation (Bolam, 2000). Models of professional development activities across the world vary greatly, and even within the same country it is possible to notice variances. The way the needs of teachers are addressed vary across nations based on policies and institutional frameworks. However, such activities do have a common pattern; that is, they either involve top-down or bottom-up approaches. Approaches that are top-down, structured and formal are generally developed by administrations or related bodies. Often, these programs invoke negative feelings towards professional development as teachers' participation is mandated by the administration regardless of their needs or particular interests. Bottom-up professional development activities, on the other hand, tend to be less formal and take teachers' needs and interests into consideration. Furthermore, they are self-initiated and attendance in such courses is voluntary as teachers participate with a genuine intent to improve instructional practices and manage their own learning (Farrell, 2013; Richards \& Farrell, 2005).

Garet, Porter, Desimone, Birman \& Yoon (2001) categorize two forms of professional development activities; traditional forms of activities and reform types of activities. The former is structured and takes place outside the classroom after school, on a weekend, or during the summer where an expert in the field disseminates information in full- or half-day activities, such as workshops, courses and conferences (Garet et al., 2001; Feiman-Nemser, 2001). Such structured activities are criticized for being ineffective as teachers do not have enough time to digest the information they receive and implement them in their classrooms. The latter, on the other hand, takes place during the school day and includes activities such as mentoring, coaching, peer observation, local study groups, ongoing seminars, collaborative research between schools and universities, teacher networks or interschool visits (Garet et al, 2001). Such activities are said to respond better to teachers' needs and goals as there is more interaction, collaboration and sharing among colleagues (Richards \& Farrell 2005; Wallace 1991). In the light of these studies, we prefer to use the term professional development activities to refer to any top-down, formal, or bottom-up, informal opportunities undertaken by teachers.

In addition to the research on professional development activities and their types, one other increasing body of research has emerged providing supporting evidence that professional development activities should focus on teachers' needs, interests and perspectives (Burns, 2005; Gonzales, Montoya and Sierra, 2002; Gravani and John, 2005; Hu, 2005; Richards and Farrell, 2005). For example, Gonzalez et al., (2002) investigated the professional development needs of $31 \mathrm{EFL}$ teachers working in Colombian secondary schools, and reported that teachers' needs may be categorized as a worker, an instructor, and a learner. They point out that the teachers' needs were predominantly emphasized in the last 2 categories. For example, as instructors, they were interested in learning about new teaching techniques, or as learners, they were keen to network with colleagues from other disciplines.

Together with professional development activities and related types, another body of research points out that workplace has a great influence on teacher professional development (Hargreaves and Fullan, 1992; Clement and Vandenberghe, 2000; Kang and Cheng, 2014; Meristo and Eisenschmidt, 2014). The common attributes of an effective workplace are collaboration and collegiality. Professional informal or formal dialogue (Mawhinney, 2010), peer supervision (observation), peer coaching, action research (Glatthorn 1987; Rodriguez and McKay 2010), teacher networks (Hofman and Dijkstra, 2010) and critical friends groups (Farrell, 2001; Poehner, 2011) are activities that support collegiality.

Although there is a rich body of literature on teacher professional development worldwide and on the theoretical aspects of what teachers should do to develop, the context specific EFL teacher professional development is under researched in our context (Eksi, 2010; Seferoğlu, 2001; Özdemir, 2013; Turhan and Arıkan, 2009). For example, Seferoğlu (2001) in his study highlighted the importance of investigating teachers' professional needs and expectations from the Ministry of Education. Using a questionnaire, he investigated how 313 teachers perceived professional development activities implemented in the Turkish education system. The findings revealed that there is lack of professional development activities in their context. Moreover, the in-service training workshops that were offered were believed to be conducted for the sake of 'formality'. 
In a recent study, Yılmaz (2015) explored the reason behind teachers' resistance to participating professional development programmes in a university in Turkey. She found out that such activities were not practical and teachers did not believe in their usefulness. Based on the teachers' needs and interests, a professional development model (named The Core, Mantle, Crust Model) which involves both top-down and bottom-up processes was developed. As the writer claims, the strength of such a model is that it is customized. In addition to being personally responsive, such programs would be contextually responsive and are thus to be more congruent with teachers' needs, interests and expectations.

In the Northern Cyprus context Hismanoğlu and Hismanoğlu's (2010) study of 42 non-native and 8 native English language teachers working at English Preparatory Schools at three different universities revealed that professional activities that were provided to them were generally workshops which teachers find boring and irrelevant to their needs. Similar findings were reported in Mertkan's (2011) study, which examined professional development opportunities provided to head teachers in Northern Cyprus.

Borg (2015) in his recently edited book underlined the lack of studies in the area of EFL teacher professional development. He further addressed the constraints and challenges EFL teachers face and the need to do more research on teachers' beliefs and attitudes towards professional development. Therefore, it is critical to understand what fosters and hinders teachers' participation in professional development activities.

\section{METHOD}

For this study, we employed a qualitative research design, which relied on the case study approach (Creswell, 2013). We utilized a multi-site data collection strategy involving three major cities in Northern Cyprus. We framed the case to be studied as the professional development of English language teachers in Northern Cyprus.

\section{Purpose}

The purpose of this particular study was to explore and understand the 12 Turkish Cypriot secondary ELT teachers' perceptions and practices of professional development. In particular, we examined; (1) teachers' visions for professional development; (2) how they have positioned their practice in relation to their development; and (3) how they have framed their 'self' in relation to professional development.

\section{Context of the study}

The study was conducted at three state schools in Northern Cyprus, located in the Mediterranean Sea. Before presenting the research design, we provide a brief note on the background and the current status of the island as this has direct impact on education and other fields. Cyprus was divided into two in 1974 as a result of inter-communal struggles between the Turkish and Greek communities. Northern Cyprus declared its independence in 1983, naming the country Turkish Republic of Northern Cyprus (TRNC), which is only recognized by Turkey. Such limited recognition and support has led to political, economic, and social challenges in Northern Cyprus. In 2003, for the first time since 1974, the TRNC decided to ease the restrictions and opened its borders to allow for more exchanges and travel between the two territories of the island. Currently, residents of the island can cross two borders (one Turkish and the other Greek) to visit either side.

\section{Participants}

The participants of the study were 12 English language teachers from three different schools and cities in Northern Cyprus. Purposeful criterion sampling was used in selecting schools. The criteria for school selection was: (1) Inner-city schools, (2) Public schools, (3) Having a large number of English language teachers. The English language teachers in the schools were informed about the purpose of the study by each of the research team members and were invited to take part. The contexts of teaching does not vary at all. All the schools are English medium state secondary schools on the island.

All the teachers, in our study, had around 15 hours of teaching English to Turkish or Turkish Cypriot secondary school students. The teachers' teaching experience varied from 3 years to 23. 6 teachers graduated from ELT department, 5 teachers from English Literature and Humanities department, and 1 teacher from Linguistics 
department. Two of the participants completed their MA in English Literature and one in TEFL. There were five participants at School 1, four participants at School 2, and three participants at School 3.

\section{Data Collection Instrument}

We chose to use semi-structured interviews as the main method because we believed that it would enable us to explore in depth the views and beliefs of these teachers related to professional development. Moreover, as teachers would have the opportunity of telling their stories related to their own development, we would have a deeper understanding of their experiences, beliefs and needs. The interview questions explored four main areas: (1) biographical questions which aimed to get background information about the teachers, (2) teachers experiences and beliefs about teaching and learning, (3) teachers' experiences, beliefs and needs related to professional development, (4) teachers' views on how professional development should be implemented.

All interviews were carried out during the school day by one of the research team members. The interviewers were responsible for asking the questions that were prepared in advance and then asking follow up questions based on the responses of the teachers in order to gather more detail about their experiences, beliefs and needs. Teachers preferred to have the interviews conducted in English. Each interview lasted 60-90 minutes and were audio recorded.

\section{Data Analysis}

All interviews were audio recorded and transcribed verbatim. The transcriptions were the primary data for interpretative analysis. The analytical process involved each researcher's initial impressionistic reading of the data and assigning descriptive codes. We then discussed the emerging list of codes and generated a coding scheme involving both descriptive and pattern codes (Miles and Huberman, 1994). Each researcher coded the data based on this coding scheme. The intercoder reliability score was satisfactory. There was $86 \%$ agreement in the coding process. The analysis of codes and the patterns emerging across the narratives led to the identification of three salient themes. These were: development, practice, and identity. In this paper, we discuss the theme 'development' and four categories related to it.

\section{FINDINGS}

In our analysis the theme development emerged with four other sub-themes. These were:

1 Development is associated with actualizing teachers' own needs.

2 Development processes are related to teachers' past experiences.

3 Teachers have varying visions for their development.

4 Teachers define development by positioning it within the larger system.

\section{Development is associated with actualizing teachers' own needs}

Our first aim was to find out how the 12 teachers viewed professional development. For these teachers, development meant fulfilment of a need. One major need they all stated was the latest trends in certain areas in language teaching--such as testing or writing. One teacher noted:

Tests are changing in our context. It is important that the students receive education and techniques in current testing that are used. Best way to develop in this area is inviting experts.

Teachers want to be in touch with experts who are leading international testing practices and get practical information on how these new applications can be used in their context. As Hall (2011) points out language testing is a "social practice" and teachers feel obliged to update their knowledge so that they can prepare their students for the International General Certificate of Secondary Education exams.

Attending workshops, seminars, and conferences also emerged as developmental needs of teachers. However, they stated that longer seminars or workshops would be more helpful than shorter ones. According to them, attending one seminar or workshop did not initiate change in their teaching. The following excerpt shows how a teacher benefited from attending a series of workshops that lasted more than a week: 
First we got some theory then we had to design our speaking exams then we tried to asses and do the assessment and everything. We tried to create a rubric. It was full of hands on practice. I feel quite ready now.

This finding is in line with Atay's (2008) 'one-shot in-service' or Farrell (2013) 'one stop workshop' where they criticize short term professional development programmes.

Taking part in international projects and spending time in the native environment of the language they are teaching is an important need as well. Being exposed to experience longer stretches of time coupled with living in the environment--where target language is spoken--have effect on the teachers' development. As Mine mentioned:

Actually workshops are effective but these are usually short ones, one week or a day, if they are longer... I mean the longer they are, the more effective and productive they are. I went to America for a month. I wish we had more and longer workshops or trainings.

OK, you can read, you can listen, study but there are some notions that you can learn only when you lived in that country. . I think these are important.

All participants emphasized the role of publishing companies in fulfilling their professional needs. Teachers try to attend those conferences. However, they all stated that they felt isolated on this island. Political and social factors make access to materials, such as books, difficult for them. One participant expressed how she and her colleagues felt as follows:

When the gates were opened, we went to Publishers Exhibition on the South, we went crazy because they were giving out things for free. I couldn't believe and this is a great opportunity because you see different publishers, different books. What is our opportunity? [Very limited] Ok, we have Internet but this is nowadays... may be in the last ten years. If I go to Deniz Plaza (a bookshop), I will not see much variety of books so we went crazy. I think we are hungry for this...

All participants repeatedly emphasized the role Ministry of Education played in their professional development. They believed that it is the responsibility of the Ministry to provide professional development opportunities. Nevertheless, all agreed on the idea that both the seminars by the Ministry of Education and the conferences by publishers are far beyond meeting their needs.

\section{Development processes are related to teachers' past experiences}

Teachers reflect on their experiences that come out of their interaction with formal and informal contexts and upon this reflection they evaluate the Self and decide whether they have developed or not. One participant, Leyla, defined what development meant to her and delicately related the concept to experience. To her, development meant a change in perspective:

Experience changes your perspective. When your perspective changes that is called development.

All teachers emphasized that development comes with experience in the classroom. Their previous experience ending with a change in perspective was defined as development and this change in perspective has an effect on what their needs are for another participant, development is being 'contemporary'. According to her:

Development takes place if you align yourself with the ideas and beliefs of the present time. It means to develop self by being in harmony with your time. In other words, you should catch the spirit of your time. 
All twelve participants value the experience of being in touch with the writers of the books they use in the classroom; they expect such communication with the experts of their field. According to them, this happens usually by inviting people--like in the South side of the island--who are number one in their field.

Merve, commenting on seminars on the South side, said:

Experiencing beneficial seminars or workshops is motivating. I always leave these meetings with this feeling: I want to do more. Why can't we do seminars and courses like this?

In other words, teachers look for similar opportunities and experiences that their peers in other countries experience. When they feel that the seminars they attend are useful, they always seem to leave the meeting with a feeling of satisfaction and gratification. However, by comparing her experience on the South, Merve questions the reasons for not having such activities on the North.

With regards to professional development and how it should be according to their previous experience, teachers talk about local seminars as well. For instance, Gaye says sharing experience with other local school teachers can be meaningful even if it is not international or official. She expressed her development after attending one local seminar as,

I want all teachers to come together; this contributes to us positively. When we come together with other teachers from other schools we see how their students reacted to the books we have just started to teach. We have a chance to compare our students' reactions and we can share experiences.

This finding confirms Clement \& Vandenberghe's (2000) contention that there are 'variations of collegiality' such as sharing stories in the school corridors, in formal meetings or in joint projects. In our study, Gaye has actually proposed to form a teacher support group or teacher network. As Richards and Farrell (2005) state such groups do not have to be formed within only one school, but several schools can come together to share and discuss ideas on teaching and learning.

Without exception all participants mentioned how they felt about the seminars organized by the Ministry of Education in the past. By relating to their past experiences, they became crystal clear about what they did not want:

I really cannot listen to a person who did not go into class for so many years, telling me what to do in class in a slideshow. Provide me with hands on experience. We need new ways in dealing with old issues. Then we can gain a perspective; and be more creative than being more standard.

What these teachers need is practical and applicable knowledge. This matches the findings of Yilmaz (2015), who also reported that teachers needed more practical professional development activities. In our study, teachers also value classroom experience highly:

A person who stayed at the university after graduation without any classroom experience will come and tell me what to do in the classroom. Honestly, I wouldn't be interested; I would laugh. For 17-18 years I taught every kind of student with every kind of obstacle so a person who has never had any experience would give me a seminar on English Language Teaching Techniques. I wouldn't be convinced.

It is clear that for these teachers professional development opportunities provided by the government are insufficient. This finding is supportive to the remark that professional development activities in Turkey are carried out by "the organizing authority generally invites an academician from a university or an experienced teacher and asks them to speak for the training activity" (Bayrakcl, 2009). However, the teachers do know what their needs are in relation to their own development. There is emphasis on communication with fellow colleagues or writers in the field. 


\section{Teachers have varying visions for their development}

Our data showed that for teachers development can be very personal and one may choose several different paths. It all depends on how a teacher envisions her/his individual capacity. Nine participants in the study mention that they picture themselves as constantly changing and reflecting on what they have done as they observe the change in their students. For them, development is ongoing and change is inevitable; it comes in several ways and in combination of the following: They imagine attending short term practical/functional seminars or conferences; getting involved in long term projects and research; and following current publications, trends and the latest technology.

They all emphasized that life-long learning can happen only if teachers love their profession, keep their interest alive and find a way to bond with their students. All participants articulated the role of the Ministry of Education and how they envision this institution contributing to their development. 7 out of 12 teachers mentioned the importance of "needs analysis" or "diagnosing the needs." They signal the need to coordinate the stakeholders, meaning a) what teachers need and want, b) students -how they change according to the times they live in, and c) the administration to organize experts or academics to prepare seminars that are addressing to both students' and teachers' needs. Rather than "jumping to prepare something for all contexts" they imagine the ministry to give well-informed decisions in choosing the topic of seminars, giving teachers freewill and choice. As mentioned before, they criticize the "one size fits all" approach.

Teachers all elaborated on the idea that individual capacity is very important and that this capacity affects a teacher's development. For many, development is actually a kind of investment where teachers "equip themselves with knowledge". One teacher remarked,

Teachers need to stay updated all the time and it is a personal endeavour.

In addition to this commitment, the following vignette identifies two important characteristics of professional development: that it should be intentional and reflective (Kabilan and Veratharaju, 2013). When defining professional development, Mine says if a teacher is aware of what she is doing, this makes her powerful:

Teachers need to become aware. I mean your job is the area you belong to.

If something is intentional, if something is professionally worked on, this makes teachers more powerful. I mean power teaching, learning and teaching professionally.

Some of the teachers find graduate studies beneficial if they see unfolding solutions in problem areas; solutions they have not imagined in their practice. One says:

You overcome your limitations because you see different aspects of the topic. If you can be sure to have this kind of expansion, you would picture self doing MA or Ph.D.

All teachers mention aligning professional development with their personal lives and talk about their realities such as lack of time. Therefore, they envision their development to be multi-staged but at the same time it should be on-going and systematic (Bayrakçı, 2009).

They all agree on the need to upgrade themselves on a personal level, however, little importance was attached to pursuing an MA. Although they found graduate studies useful, they did not prioritize it.

\section{Teachers define development by positioning it within the larger system}

The third concept in relation to development--and especially professional development--is system's positioning development in the discourse of institutions. It is quintessential for teachers that development is appreciated and supported by institutions and policy makers; the opportunities created and the barriers set in their path by the powerful have utmost importance. In the discourse of secondary school teachers, the powerbase appears to be the government system and as its representative the Ministry of Education and following that they list the school administration.

One participant Müge defined the system as a barrier hindering them to act as change agents: 
About the government system working here, many teachers feel they are not happy with the situation because they feel their efforts do not have any impact so they give up trying. I wish we had a different system so that we can keep up with contemporary things.

Gaye points out how she wants to be engaged in self-directed learning (Smith, 2003; Richards and Farrell, 2005) and wishes to set her goals and become a change agent. She envisions the changes she would bring to her system, if she were in power:

I like to improve myself doing the autonomous learning stuff ... if I had the power at school and in making decisions or the responsibility at the ministry I would say [to the teachers] "OK you can do whatever you want;"

This finding is consistent with research undertaken by Phillips (2003). She concludes that when teachers are involved more in decision-making process, professional development became increasingly individualized which helped them become reflective practitioners. Therefore, if teachers would have the chance to become decision-makers in designing such activities, they would create more relevant and meaningful professional development activities.

Although there are several professional development activities organized by the Ministry of Education on the southern side of the island teachers can participate in such activities on a voluntary basis as there is a logistic barrier: "attending these activities would be problematic because within the daily rush of our schedule it would be difficult to drive" to the other side as there is a need to go through two check-points.

Participants also acknowledge the opportunities created by another resource that is feeding the system; the European Union. For instance, Gaye describes the opportunities as following:

As Turkish Cypriots we have some chances like European ... programs that are specially designed for us. So you can get those scholarships and go abroad and do some courses. So European Union is financing.

This comment shows that there are actually opportunities created by a larger system. However, teachers are still required to make an effort to reach out to such opportunities. Nevertheless, they all point to the fact that the Ministry of Education should support teachers' professional development through the school system or other governing bodies. One teacher says:

Teacher development should be part of the school system and maybe it should be something voluntary, but should be encouraged with promotion.

\section{DISCUSSION \& CONCLUSION}

The aim of this study was to explore the experiences of secondary EFL teachers and present their voices regarding their professional development experiences and needs. Based on the findings, it is possible to assume that teachers' teaching context, experience, government and the personal 'self' influence their perceptions about professional development.

This study revealed that the teachers, by and large, seem to be dissatisfied with the current professional development activities provided by the governing bodies. Although they attend the professional development activities provided by the Ministry, they find such activities useless and time-consuming. One key issue that emerged from our data is collaboration between other schools. They believe that collaboration between the schools would allow them to share their experiences and learn from each other (BayrakCl, 2009). Teachers also repeatedly expressed that professional development activities need to be relevant to their classrooms. Attending the conferences or workshops which do not meet their needs and interests have been expressed as time-consuming and irrelevant. These outcomes are in line with the findings of Sato, Chung and Darling-Hammond (2008), Kabilan and Veratharaju (2013) and Özdemir (2013) who found that collaboration and networking with colleagues from other schools would effectively contribute to teachers' professional development and learning. There is clear evidence from our study that the activities provided 
to the teachers in our context are top-down and one-size-fit-all type rather than bottom-up. In other words, teachers are expected to attend such professional development activities just for the sake of being there. However, these teachers are aware of their needs and do not want to participate in activities that will not contribute to their development. Richards and Farrell (2005) note that professional development activities need to meet the needs of both the institution and its teachers.

Another similar key issue that emerged from this study is that the teachers are hungry for various professional development activities. In other words, they are all eager to improve their practice so that they can serve better to their students. Moreover, they want to keep abreast of new developments in teaching, gain mastery of new skills, and continue to reflect on their practise. This result is in line with research by Kabilan and Veratharaju (2013) which shows that one area teachers' need to improve themselves in gaining new content, pedagogical knowledge and teaching skills. In the current study, the lack of various professional development activities and the support provided by the government need to be strengthened and improved.

The last important issue that arose from our study was related to teachers' positioning themselves within the whole system. All the teachers in the study stated that their efforts in relation to their development seem to be regarded as worthless both by the school and the Ministry. Therefore, some of the teachers stated that they do not want to take the initiative to engage in professional development activities. Furthermore, unfortunately, due to the current political and financial situation of the government, teachers do not receive much financial aid for their development. Even if they wanted to engage in a professional development activity, either their identity or their financial situation hindered them from pursuing.

Our study presented some insight into teachers' perceptions of professional development. Based on these insights, the following implications can be taken into consideration:

- Teachers are interested in current trends in language teaching and they are eager to keep pace with professional activities. However, they state that these activities should be carried out in longer stretches of time in a systematic manner.

- Teachers actually favour bottom up decision making processes in deciding about their needs. Therefore, the Ministry of Education should conduct a needs analysis and identify teachers' needs and interests. After the results, they should design both short-term and long-term teacher development activities.

- Professional development is a self-directed process. However, more opportunities should be created by the Ministry of Education and school administrations for teachers to participate in professional activities (workshops, conferences, involving in projects, etc.) abroad and/or at home. Additionally, teachers should be financially supported to attend such activities or to carry out projects.

- Schools can be encouraged to form teacher networks during the school year. Such collaborative activities, which should be held regularly, are likely to strengthen collegiality for the benefit of students and perhaps give them the confidence to act as change agents. Sharing experiences with their colleagues during the school year will encourage teachers to apply what they learn from each other.

We believe that providing these teachers and teachers under similar conditions with the above-mentioned opportunities would produce high quality teaching. The ultimate goal in teaching is to improve student achievement. One way to reach this goal would be to institutionally support teachers in their teaching lives. Governing bodies should not underestimate "how adults learn, how they prefer to learn, and what they want to learn" (Burden, 1990, p. 325).

\section{LIMITATIONS \& SUGGESTIONS FOR FURTHER RESEARCH}

There are some limitations in our study. First, due to a limited number of participants, the findings of this study may not be generalizable to teachers from other countries or contexts. Had the study been carried out in different contexts, i.e. private schools, the findings would have been different as the teachers in those school are required to attend professional development activities periodically. Second, the study was carried out with only English language teachers. Other subject matter teachers can be involved in such studies to identify their needs and interests in relation to teacher development. 
Through this research we found out that teachers do not favor top-down decision making processes about their needs as they do not have a say in this structure. As one of our participants mentioned it would be informative and valuable to learn about the criteria the ministry uses to understand the needs of the teachers. (How do they know what teachers' needs are? How are areas of needs decided? How are seminar/workshop topics chosen? Who chooses the speakers to be invited?) Further research can be insightful in understanding the viewpoints of administrators in decision making. There is a need to explore policymakers and administrators' decision-making processes. Once this is understood further research can be how to establish a bottom-up/top-down structure in teacher development activities organized by Ministry of Education in a systematic manner.

\section{REFERENCES}

Atay, D. (2008). Teacher research for professional development. ELT Journal, 2(62), 139-147.

Bayrakcı, M. (2009). In-Service Teacher Training in Japan and Turkey: a Comparative Analysis of Institutions and Practices. Australian Journal of Teacher Education, 34(1).

Bolam, R. (2000). Emerging policy trends: some implications for continuing professional development. Journal of In-service Education, 26(2).

Borg, S. (Ed.). (2015). Professional development for English language teachers: Perspectives from higher education in Turkey. Ankara: British Council.

Burden, P.R. (1990). Teacher development. In Houston, R. W. (ed.), Handbook of Research on Teacher Education. New York: Macmillan, 311-328.

Burns, C. (2005). Tensions between national, school and teacher development need survey of teachers" views about continuing professional development within a group of rural primary schools. Journal of In-Service Education, 31(2), 353- 372.

Clement, M., \& Vandenberghe, R. (2000). Teachers' professional development: A solitary or collegial adventure? Teacher and Teaching Education, 16, 81-101.

Creswell, J. W. (2013). Qualitative Inquiry \& research design. Choosing among five approaches. (3rd ed.). Thousand Oaks: Sage Publications.

Ekşi, G. (2010). An assessment of the professional development needs of English language instructors working at a state university. Unpublished Master's Thesis, Middle East Technical University, Ankara, Turkey.

Farrell, T.S.C. (2001). Critical Friendships: colleagues helping each other develop. ELT Journal, 55, 368-374.

Garet, M. S, Porter, A. C, Desimone, L., Birman, B, \& Yoon, K. S. (2001). What makes professional development effective? Results from a national sample of teachers. American Educational Research Journal, 38(4), 915-945.

Glatthorn, A. (1987). Cooperative professional development: Peer centered options for teacher growth. Educational Leadership, 45(3), 31-35.

Gonzalez, A., Montoya, C., \& Sierra, N. (2002). What do EFL Teachers Seek in Professional Development Programs? Voice from Teachers. Ikala, revista de lenguaje y cultura, 7(13).

Gravani, M. N., \& John. P. D. (2005). 'Them and us': Teachers' and tutors' experiences of a 'new' professional development course in Greece, Compare: A Journal of Comparative and International Education, 35(3), 303-319.

Hargreaves, A. \& Fullan, M. (1992). Introduction. In A. Hargreaves \& M. Fullan (Eds.), Understanding Teacher Development (pp. 1-19). Columbia: Teachers College Press.

Hismanoglu, M. \& Hismanoglu, S. (2010). English language teachers' perceptions of educational supervision in relation to their professional development: a case study of Northern Cyprus. Novitas-royal. Research on Youth and Language, 4(1).

Hofman, R.H. \& Dijkstra, B.J. (2010). Effective teacher professionalization in networks? Teaching and Teacher Education, 26, 1031-1040.

$\mathrm{Hu}, \mathrm{G}$. (2005). Professional development of secondary EFL teachers: Lessons from China. Teachers College Record, 107(4), 654-705.

Kabilan, M.K. \& Veratharaju, K. (2013). Professional development needs of primary school English language teachers in Malaysia. Professional Development in Education, 39(3), 330 - 351. 
Kang, Y., \& Cheng, X. T. (2014). Teacher learning in the workplace: A study of therelationship between a novice EFL teacher's classroom practices and cognition development. Language Teaching Research, 18(2), 169-186.

Mawhinney, L. (2010). Let's lunch and learn: Professional knowledge sharing in teachers' lounges and other congregational spaces. Teaching and Teacher Education, 26, 972-978.

Meristo, M., \& Eisenschmidt, E. (2014). Novice teachers' perceptions of school climate and self-efficacy. International Journal of Educational Research, 67, 1 - 10.

Miles, M. B., \& Huberman, A. M. (1994). Qualitative data analysis. Thousand Oaks: Sage Publications.

Özdemir, S. M. (2013). Exploring the Turkish Teachers' Professional DevelopmentExperiences and Their Needs for Professional Development. Mevlana International Journal of Education, 3(4), 250-264.

Phillips, J. (2003). Powerful learning: Creating learning communities in urban school reform. Journal of Curriculum and Supervision, 18(3), 240-258.

Poehner, P. (2011). Teacher learning through critical friends group: Re-contextualizing professional development in a K-5 school. In K.E. Johnson \& P.R. Golombek (Eds.), Research on second language teacher education: A sociocultural perspective on professional development, (pp. 189-203). New York, NY: Routledge.

Richards, J. C., \& Farrell, T. S. C. (2005). Professional development for language teachers: Strategies for teacher learning. New York, NY: Cambridge University Press.

Rodriguez, A. G., \& McKay, S. (2010). Professional development for experienced teachers working with adult English language learners. Washington, DC: Center for Applied Linguistics. Retrieved from http://lincs.ed.gov/lincs/resourcecollections/abstracts/workforce/RC_work_abs92

Sato, M., Chung, R. R., \& Darling-Hammond, L. (2008). Improving teachers' assessment practices through professional development: The case of national board certification. American Educational Research Journal, 45(3), 669-700.

Seferoğlu, S. S. (2001). Elementary school teachers' perceptions of professional development. Hacettepe University, Journal of Education, 20, 117-125.

Turhan, I. E. \& Arıkan. A. (2009). English language teacher development with and without a teachertrainer: ELT instructors' perceptions, E-journal of New World Sciences Academy, 4(2), 410-421.

Yılmaz, Y. Y. (2015). Dealing with teacher resistance. In Borg, S. (ed.), Professionaldevelopment for English language teachers: Perspectives from higher education in Turkey. Ankara: British Council.

Wallace, M. J. (1991). Training foreign language teachers: A reflective approach. New York: Cambridge University Press.

Correspondence

Dr. Alev ÖZBILGIN

Middle East Technical University, NCC

TEFL Program

ozbilgin@metu.edu.tr

Dr. Besime ERKMEN

Middle East Technical University, NCC

TEFL Program

berkmen@metu.edu.tr

Assoc. Prof. Dr. A. Cendel KARAMAN

Middle East Technical University, Ankara

Foreign Language Education

cendel@metu.edu.tr 
